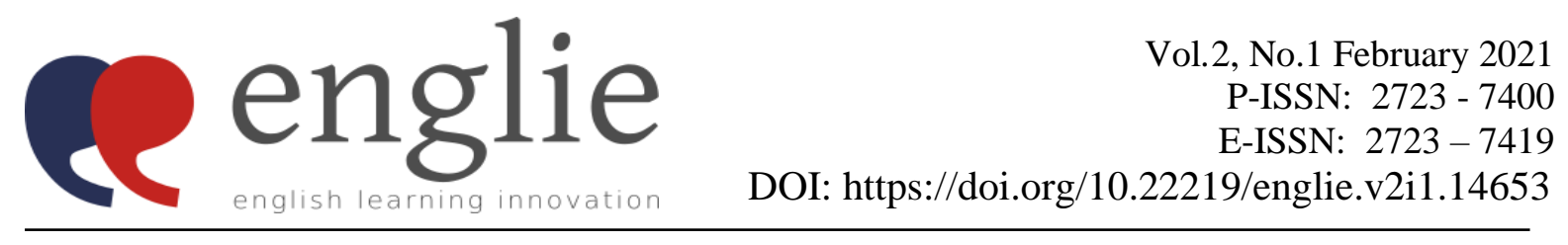

\title{
Flipped Learning Instruction and Pragmatic Competence: A Case of English for Accounting Students
}

\author{
Arif Nugroho \\ IAIN Surakarta, Indonesia \\ Corresponding Author: arif.nugroho@iain-surakarta.ac.id \\ Rahima Fitriati \\ Universitas Muhammadiyah Malang, Indonesia
}

\begin{abstract}
Nowadays, English language teaching is the witness of advanced Information and Communication Technology (ICT). Integrating digital technologies in English teaching activities is a prerequisite to enhance learning efficacy and achieve the goal of English communicative competence. Hence, this study examines the impact of flipped learning instruction on pragmatic competence of a group of English for specific purposes students, i.e. English for Accounting. This pre-experimental study was conducted in ten meetings by involving 36 English for Accounting students of a public university in Surakarta Indonesia as the participants. Drawing on a Discourse Completion Test (DCT) and Focus Group Discussion (FGD), the results portrayed that there was a significant difference between the results of pre-test and post-test on DCT, meaning that the students' pragmatic competence significantly improved after participating in the flipped learning instruction. A FGD was further conducted to reveal the students' attitudes about the practice of flipped learning and the results indicated that they positively perceived the implementation of the teaching model in English for Accounting class. These results contribute to offering fruitful insights for teachers and future researchers about the practice of flipped learning instruction in English language teaching, particularly in the context of English for specific purposes.
\end{abstract}

Keywords: English for Accounting, Flipped Learning, Pragmatic Competence

\section{INTRODUCTION}

English language teaching stakeholders can surely remember the situation of learning activities implemented in about two decades ago. The students were occasionally sitting and inactively listening to the material explanation and instruction from their teachers. Instead of actively participating in learning activities, they were passively given concepts and information. They were also perceived as an empty glass that should be filled in the teachercentered learning instruction. For years, English language teaching had been devoted to language accuracy than language fluency, thus the learning of language function in real communication seemed to be put aside (Muthusamy \& Farashaiyan, 2016; Nugroho \& Rekha, 2020). However, in the age of the advanced digital technology and communication, a more learner-centered teaching model has extensively been administered by combining traditional 
teaching with technology-based learning activities (Cahyono \& Mutiaraningrum, 2015). Scholars in English language teaching refer to this learning method as a blended learning that enables the sharing of teachers and students role to create an active learning environment (Bonk \& Graham, 2012). By the time of its development, the literature in English language teaching acknowledged blended learning as a more interactive teaching method called flipped classroom (Chen Hsieh et al., 2017; O’Flaherty \& Phillips, 2015).

The idea of flipped learning was firstly coming up when Bergmann and Sams (2012) looked for an effective teaching method for the absent students to have an access on the class lessons and materials. They recorded the lessons and made use of a digital platform to post the recordings online so that the students who did not join the class still be able to follow the learning materials by watching the videos at any time and any place. Then, they found out that the model of learning greatly helped students who could not attend the class. Surprisingly, the students who attended the class could also watch the videos and this activity helped them review and revisit the day's lessons. It initiates the concept of massive integration of digital technology in English language teaching called flipped learning instruction (Bergmann \& Sams, 2012; Chen et al., 2014). As a part of blended learning, flipped classroom design offers ample opportunities for students prior to, amidst, and after the class because of its flexibility (Bergmann \& Sams, 2012). Flipped learning instruction enables teachers to share learning materials such as videos, games, or music before the class (Zainuddin \& Perera, 2019), and the teaching activities in the class are mostly devoted to performing group tasks, practicing conversation, doing collaborative projects, and conducting extensive discussion based on the materials that have been previously shared prior to the class (McLaughlin et al., 2016).

English language teaching practitioners have examined the potentials of flipped learning method in various learning contexts and education backgrounds. Lockwood (2014) acknowledged that flipped learning significantly contributed to students' higher-order thinking skills such as the ability to perform analysis, application, evaluation, and synthesis. Zainuddin and Perera (2019) found that students who were taught using flipped learning instruction were more competent in handling online tasks and learning activities, and were able to control their learning outcomes. Another finding of Zainuddin and Perera's (2019) study was that the students were highly motivated by the video-recorded lectures, self-regulated learning environments, and peer interactions. In a similar direction, Singay (2020) investigated the impact of flipped learning on Bhutanese students' grammatical competence and the results demonstrated that the flipped learning could significantly improve the students' language accuracy. In the context of English language teaching in the United States, Webb and Doman (2020) examined self-reported attitudes of a group of students about technology-enhanced language learning in the flipped classroom. The results portrayed that flipped-learning students showed a statistically difference in all self-reported attitudes in using technology-enhanced language learning overtime.

In Indonesian context of English language teaching, there have been conducted studies examining the practice of flipped learning. Afrilyasanti, Cahyono, and Astuti (2017) investigated flipped classroom instructions contributed to Indonesian learners' writing ability and the results pointed out that there was a significant score difference in the learners' pre-test and post-test between the flipped group and control group. The finding indicates a promising contribution of the flipped learning model to improve students' writing skills. Furthermore, Hasanudin and Fitrianingsih (2018) sought for an empirical relationship between flipped learning and the development of Indonesian learners' reading skills. Drawing on the use of Screencast-O-Matic apps, the results revealed that flipped learning significantly contributed to the successful enhancement of the students' reading ability. The study also suggests that the combination between face-to-face teaching and digital technology-based learning in a language classroom creates innovation of teaching reading in the Indonesian context. Therefore, it is a 
worth saying that flipped learning environment created promising peer interaction and independent learning among the learners (Webb \& Doman, 2020).

In terms of pragmatic competence, Haghighi's et al. (2019) study seems to be the initial research conducted to reveal the effect of flipped learning on English learners' language fluency. Using Telegram in the Iranian context, the study found a positive correlation between flipped classroom instruction and learners' pragmatic competence. More recently, a study conducted by Hazaymeh and Altakhaineh (2019) indicated that flipped learning method had a significant effect on Emirati students' pragmatic competence. These studies (e.g. Haghighi et al., 2019; Singay, 2020; Hazaymeh \& Altakhaineh, 2019) suggest that an immense project by involving the greater size of participants and different context should be conducted to confirm the results of their investigation. Keeping this in mind, this experimental study attempts to fill the gap by shedding some light on the impact of flipped classroom instruction on a group of learners' pragmatic competence in the Indonesian context.

While several previous studies have addressed the impact of flipped learning on various settings (Afrilyasanti et al., 2017; Haghighi et al., 2019; Hasanudin \& Fitrianingsih, 2018; Singay, 2020; Hazaymeh \& Altakhaineh, 2019; Zainuddin \& Perera, 2019), it appears that almost no study, to the best of the authors' knowledge, has examined the effect of flipped learning method on students' pragmatic competence in Indonesian ELT context. The growing body of literature in the realm of pragmatics has shown that pragmatic competence, which is the ability to use language in an appropriate context, is teachable in a language learning context (Alzeebaree \& Yavuz, 2017; Celce-Murcia et al., 1995; Yazdanfar \& Bonyadi, 2016). Although some linguists argue that it seems difficult to teach pragmatics (Kasper \& Schmidt, 1996; Krisnawati, 2011), the integration of pragmatic knowledge in a language classroom is considered highly essential especially for context in Indonesia where classroom is the only place for the students to get language exposure (Nugroho et al., 2020).

In order to close the research gaps, the in-hand study aims to shed some light on the impact of flipped learning instruction on English for Accounting students' pragmatic competence, which becomes one of the crucial skills to assist the development of their future careers in finance and business fields. Moreover, this study reveals the students' perceptions toward the practice of flipped learning instruction in their class. What else puts this study differs from the previous research (Haghighi et al., 2019b; Hazaymeh \& Altakhaineh, 2019) is that the way it employs Google classroom as a digital platform to facilitate the delivery of learning materials in the flipped learning instruction. To ensure the objectives, this study is guided by two research questions: (1) Does flipped learning instruction provide an impact on English for Accounting students' pragmatic competence? (2) What is the perception of English for Accounting students toward the practice of flipped learning instruction?

\section{METHOD}

\section{Rationale of the Method}

To address the research questions, a pre-experimental design administering pre-test and post-test to the participants was conducted. An experimental research is a scientific approach in which one or more independent variables are applied to dependent variables to measure the effect (Phakiti, 2015). In this study, the pre-experimental design was adopted to examine the impact of flipped learning instruction on English for Accounting students' pragmatic competence. Following the results of experimental research, a FGD was further conducted to reveal the students' perceptions toward the practice of flipped learning in their class.

\section{Participants and Setting}

The present study was conducted in Indonesian context of English language teaching where English is considered as a foreign language, so that the most available place for students 
to get a lot of exposure of the language is formal classroom (Nugroho, 2020). This study was taken place in an English for specific purposes teaching at a public university in Surakarta Indonesia. The participants were the 34 freshmen ( 25 female and 9 male) of English for Accounting class at odd semester of academic year 2019/2020. All participants are native speaker of Indonesian and consider English as their foreign language. Their ages were 18 up to 20 and the average was 19.

\section{Instrumentation and Data Collection}

This study administered 10 meetings including pre-test and post-test on Discourse Completion Test (DCT) to examine their development of pragmatic competence. DCT is an assessment tool firstly developed by Blum-kulka and Olshtain (1984) that is utilized in the realm of linguistics and pragmatics to evaluate certain speech acts (in this study is requesting act). This kind of task is a written questionnaire that comprises some concise contextual descriptions, followed by a blank space for the speech act responses (Alzeebaree \& Yavuz, 2017). The DCT situational descriptions explicitly inform the participants about the roles they have to play. Moreover, by referring to the described situations, the participants are required to give responses in the provided blank spaces. In this study, the data were gathered using a DCT consisted of 12 contextual situations involving some social variables adapted from Nugroho (2019). The situations were contextualized with the day-to-day interactions that were commonly encountered by the participants involved in this study.

After conducting the pre-test, the participants were taught using flipped learning instruction for eight meetings and experienced inside and outside classroom activities. Prior to the class, the teacher posted videos about daily conversation in Google classroom platform to equip the students with cross-cultural understanding and pragmatic awareness. During teaching activities in the class, the students mostly performed peer interaction and discussion such as practicing conversation, speaking formal and informal communication, presenting ideas and opinion, and doing peer projects. In the tenth meeting, another series of DCT was administered as the post-test to examine the participants' improvement in pragmatic competence after being taught using flipped learning instruction in eight meetings. Following the post-test, a FGD was conducted by involving 8 selected participants (namely P1-P8) to reveal their point of views about the practice of flipped learning instruction in their class. The FGD was last for 45 minutes when each students had a chance to deliver their opinion and respond to the other participants' ideas.

\section{Data Analysis}

Two raters were involved in scoring the results of pre-test and post-test. The first rater was one of the researchers and the second rater was a native speaker teaching at a private university in Surakarta Indonesia. This study made use of Rating scale of appropriateness (Taguchi, 2006) to score the participants' responses obtained from DCT. The scoring rubric consisted of 6 points Likert-scale ranged from "Zero performance (0)" to "Excellent (10) to ensure higher inter-ratter reliability (see table 1). The mean score, along with standard deviation and standard error mean, of the pre-test and post-test were calculated by means of SPSS. To determine whether the two mean scores have significant difference, a paired sample t-test was administered. Moreover, with regards to the results of FGD were noted and coded to see the emerging theme based on the research question of this study. During the process of coding, the researchers have simplified, analyzed, and reviewed the most relevant data that later were used as a basis of conclusion drawing. To maintain the validity and reliability, the two researchers independently coded the results of FGD and conducted a series of discussion to achieve the consensus of conclusion drawing. 
Table 1. Rating scale of appropriateness

\begin{tabular}{|c|c|c|}
\hline Rating & Points & Criteria \\
\hline Excellent (5) & 10 & $\begin{array}{l}\text { - The request expressions are fully appropriate based on the } \\
\text { provided contextual situations } \\
\text { - } \text { The request expressions are free of grammatical mistakes }\end{array}$ \\
\hline Good (4) & 8 & $\begin{array}{l}\text { - The request expressions are almost suitable } \\
\text { - The request expressions comprise a small number of } \\
\text { grammatical mistakes but still understandable }\end{array}$ \\
\hline Fair (3) & 6 & $\begin{array}{l}\text { - The request expressions somehow acceptable } \\
\text { - The request expressions comprise several grammatical } \\
\text { mistakes }\end{array}$ \\
\hline Poor (2) & 4 & $\begin{array}{l}\text { - The request expressions are not appropriate because of } \\
\text { grammatical mistakes }\end{array}$ \\
\hline Very poor (1) & 2 & $\begin{array}{l}\text { - The request expressions are not understandable because } \\
\text { of wrong responses and heavy grammatical mistakes }\end{array}$ \\
\hline$(0)$ & 0 & No request expressions are produced \\
\hline
\end{tabular}

\section{FINDINGS AND DISCUSSION}

\section{Impact of Flipped Learning on Students' Pragmatic Competence}

The first result of data analysis is the impact of flipped learning instruction on English for Accounting students' pragmatic competence. The mean scores of pre-test and post-test obtained from DCT were calculated to portray the students' pragmatic development. The result showed that there was a difference between the students' scores in pre-test and post-test. The detailed result is presented in table 2 .

Table 2. Results of Pre-test and Post-test

\begin{tabular}{lcccc}
\hline & Mean & N & Std. Deviation & Std. Error Mean \\
\hline Pre-test & 5.35 & 34 & 5.167 & 2.378 \\
\hline Post-test & 7.80 & 34 & 9.325 & 1.964 \\
\hline
\end{tabular}

Table 2 demonstrates the difference between the students' scores of pre-test and posttest. The mean score of the students in pre-test and post-test are 5.35 and 7.80 respectively. To determine whether the two scores have a significant difference, a paired sample t-test was conducted. The result can be seen in table 3 .

Table 3. Results of Paired Sample t-test

\begin{tabular}{|c|c|c|c|c|c|c|c|c|c|}
\hline \multicolumn{5}{|c|}{ Paired Differences } & \multicolumn{2}{|c|}{$\begin{array}{l}95 \% \text { Confidence } \\
\text { Interval of the } \\
\text { Difference }\end{array}$} & \multirow[b]{2}{*}{$\mathbf{t}$} & \multirow[b]{2}{*}{ Df } & \multirow[b]{2}{*}{$\begin{array}{c}\text { Sig. } \\
\text { (2-tailed) }\end{array}$} \\
\hline & & Mean & $\begin{array}{c}\text { Std. } \\
\text { deviation }\end{array}$ & $\begin{array}{l}\text { Std. Error } \\
\text { Mean }\end{array}$ & Lower & Upper & & & \\
\hline Pair 1 & $\begin{array}{l}\text { Pre-test } \\
\text { Post-test }\end{array}$ & -2.45 & 4.13 & 0.59 & -1.61 & -1.38 & -2.241 & 35 & .000 \\
\hline
\end{tabular}

Table 3 depicts that the t-test statistics is -2.241 and the significant level is $.000(<.05)$, meaning that there is a significant difference between the results of students' pre-test and posttest. The table also portrays that the average score of the participants in the post-test is 2.45 (on scale 10) points higher than the pre-test. Hence, this result suggests that the null hypothesis is rejected. The result of paired sample t-test emphasizes that the students perform better after being taught using flipped learning instruction in eight meetings. 


\section{Students' Perception on the Practice of Flipped Learning Instruction}

The results of FGD portrayed the participants' point of views about the practice of flipped learning instruction in English for Accounting class. In general, the participants positively perceived the use of flipped learning model to enhance their communicative competence, particularly pragmatic competence. The majority participants in the FGD stated that flipped learning classroom is enjoyable and effective to help them learning English communication. Students found that the flipped learning approach created a conducive learning environment since they could access video materials whenever they were available. Some of the participants in FGD said:

"yes, the teaching activities in flipped classroom are very interesting. I feel more enjoy practicing English conversation. These activities made us having more practices that is very helpful to us." (P.7)

"everyone in this class stays focus and try to perform the task given by the teacher seriously. It makes the learning situation conducive without too much noisy." (P.2)

"hmmm.... I understand that actually we are more interested in learning activities when they are carried out using technology and entertainment. So, this learning strategy is very effective to attract the students' attention." (P1)

Moreover, creating better relationship and collaboration amongst the classmates was one of the benefits shared by the participants in flipped classroom instruction. Using flipped learning in the classroom can particularly develop collaboration since most of the learning activities enable students to actively participate in the activities. In addition, the students were more motivated to have conversation practices that enhanced their cultural understanding and pragmatic awareness. As some of the participants reflected:

"flipped learning instruction requires us to actively involved in teaching activities and have communication and collaboration with other classmates." (P.4)

"because we have a lot of discussion in this flipped learning, it can improve the collaboration and relationship between one student and other students. " (P.6)

“..... and in the flipped learning, we are able to perform more collaborative learning activities because most of them are done in pairs or groups which need collaboration among the members." (P.5)

The data analysis shows compelling results. In regards to the first research question about the impact of flipped learning on students' pragmatic competence, the result shows that there is a significant difference between the results of pre-test and post-test. It suggests that flipped learning instruction provides a significant impact on the development of students' pragmatic competence. This result confirms the studies of Haghighi et al. (2019) and Hazaymeh \& Altakhaineh, 2019) that flipped learning is found to be a promising method to enhance the students' pragmatic competence. In the age of advanced technology and communication, integration of digital learning platforms in English language teaching is highly necessary to foster the students' learning outcomes (Lee, 2019; Nugroho \& Atmojo, 2020). Besides, learning activities using digital technology can also be conducted by means of several learning management systems (e.g. Moodle, Edmodo, Google classroom) and social media (e.g. Instagram, Facebook, Youtube) in various ways (Alwehaibi, 2015; Gatcho \& Hajan, 2019; Mutiaraningrum \& Nugroho, 2020; Nugroho \& Rahmawati, 2020). These digital platforms are 
potentials to facilitate the practice of flipped learning instruction in English language teaching classrooms.

As for the second research question, the results of FGD indicate that the students show a positive perception toward the implementation flipped learning instruction in their English for Accounting class. In this study, the students believe that flipped learning instruction creates a conducive learning environment and develops collaboration among them. This finding is relevant to what has been found by Singay (2020) that the students show a positive perception toward the teaching activities in flipped learning classroom. The finding also supports the result of study reported by Webb and Doman (2020) that students have positive attitudes toward the flipped learning instruction. It is undeniable that technology cannot be separated from presentday students' daily life and habits (Nartiningrum \& Nugroho, 2020). Therefore, instead of preventing the use of technology by the students, English language teachers are strongly suggested to integrate digital devices such as smartphones, tablets, and computers into the students' learning activities to enhance their communicative competence (Haghighi et al., 2019; Lee \& Drajati, 2019; Nugroho \& Mutiaraningrum, 2020).

The results of this study have several implications for English language teaching. First, examining the positive impact of flipped learning instruction on students' pragmatic competence is a significant effort to find out an alternative approach for teaching pragmatics. Drawing on the results of this study and other relevant findings, English language teachers can design flipped learning activities by integrating digital technologies in classroom, particularly in English as a foreign language teaching. Second, the results of this study become "a wake-up call" for English language teaching stakeholders (e.g. teachers and school authorities) to begin acknowledging the positive impact of flipped learning on students' language ability, especially in the context of teaching English for specific purposes. This study suggests that there is an opportunity to integrate flipped learning instruction into school curricula of English language teaching in Indonesia.

\section{CONCLUSION}

Drawing on the findings and discussion, the present study depicts that flipped learning instruction provides significant impact on English for Accounting students' pragmatic competence. The students show positive attitudes toward the practice of flipped learning in their classroom. These results contribute to providing fruitful insights for English language teachers about the flipped classroom design in English language teaching. Despite the compelling results, this study acknowledges that the number of participants cannot be used as a basis of generalization of the results in a large population of English language teaching contexts around the world. Therefore, future studies are suggested to conduct an immense project examining the impact of flipped learning instruction on students' pragmatic competence by involving greater number of participants coming from different cultural and educational backgrounds. Lastly yet importantly, future studies are also encouraged to examine other aspects of communicative competence such as grammatical competence, discourse competence, and sociolinguistic competence.

\section{REFERENCES}

Afrilyasanti, R., Cahyono, B. Y., \& Astuti, U. P. (2017). Indonesian EFL students' perceptions on the implementation of flipped classroom model. Journal of Language Teaching and Research, 8(3), 476. https://doi.org/10.17507/jltr.0803.05

Alwehaibi, H. O. (2015). The impact of using YouTube in EFL classroom on enhancing EFL students' content learning. Journal of College Teaching \& Learning (TLC), 12(2), 121126. https://doi.org/10.19030/tlc.v12i2.9182 
Alzeebaree, Y., \& Yavuz, M. A. (2017). Realization of the speech acts of request and apology by middle eastern EFL learners. Eurasia Journal of Mathematics, Science and Technology Education, 13(11), 7313-7327. https://doi.org/10.12973/ejmste/79603

Bergmann, J., \& Sams, A. (2012). Flip your classroom: Reach every student in every class every day. International society for technology in education.

Blum-kulka, S., \& Olshtain, E. (1984). Requests and apologies: A cross-cultural study of speech act realization patterns (CCSARP). Applied Linguistics, 5(3), 196-213. https://doi.org/10.1093/applin/5.3.196

Bonk, C. J., \& Graham, C. R. (2012). The handbook of blended learning: Global perspectives, local designs. John Wiley \& Sons.

Cahyono, B. Y., \& Mutiaraningrum, I. (2015). Indonesian EFL teachers' familiarity with and opinion on the internet-based teaching of writing. English Language Teaching, 9(1), 199. https://doi.org/10.5539/elt.v9n1p199

Celce-Murcia, M., Dörnyei, Z., \& Thurrell, S. (1995). Issues in Applied Linguistics authors model with content specifications. Issues in Applied Linguistics, 6(2), 5-35.

Chen Hsieh, J. S., Wu, W.-C. V., \& Marek, M. W. (2017). Using the flipped classroom to enhance EFL learning. Computer Assisted Language Learning, 30(1-2), 1-21.

Chen, Y., Wang, Y., \& Chen, N.-S. (2014). Is FLIP enough? Or should we use the FLIPPED model instead? Computers \& Education, 79, 16-27.

Gatcho, A. R. G., \& Hajan, B. H. (2019). "Check Your Face(Book) on Page...”: Unpacking the Pedagogical Potentialities of English Teachers' Wall Posts. Lingua Cultura, 13(1), 1. https://doi.org/10.21512/lc.v13i1.5253

Haghighi, H., Jafarigohar, M., Khoshsima, H., \& Vahdany, F. (2019). Impact of flipped classroom on EFL learners' appropriate use of refusal: achievement, participation, perception. Computer Assisted Language Learning, 32(3), 261-293.

Hasanudin, C., \& Fitrianingsih, A. (2018). Flipped classroom using Screencast-O-Matic apps in teaching reading skill in Indonesian language. International Journal of Pedagogy and Teacher Education, 2, 16-151.

Hazaymeh, W. A., \& Altakhaineh, A. R. M. (2019). The effect of flipped classroom instruction on developing emirati EFL learners' pragmatic competence. International Journal of Learning, Teaching and Educational Research, 18(10), 89-111. https://doi.org/10.26803/ijlter.18.10.6

Kasper, G., \& Schmidt, R. (1996). Developmental issues in interlanguage pragmatics. Studies in Second Language Acquisition, 18(2), 149-169.

Krisnawati, E. (2011). Pragmatic competence in the spoken english classroom. Indonesian Journal of Applied Linguistics, 1(1), 105-115. https://doi.org/10.17509/ijal.v1i1.102

Lee, J. S. (2019). Informal digital learning of English and second language vocabulary outcomes: Can quantity conquer quality? British Journal of Educational Technology, 50(2), 767-778. https://doi.org/10.1111/bjet.12599

Lee, J. S., \& Drajati, N. A. (2019). English as an international language beyond the ELT classroom. ELT Journal, 73(4), 419-427. https://doi.org/10.1093/elt/ccz018

Lockwood, R. B. (2014). Flip it!: Strategies for the ESL classroom. University of Michigan Press.

McLaughlin, J. E., White, P. J., Khanova, J., \& Yuriev, E. (2016). Flipped classroom implementation: a case report of two higher education institutions in the United States and Australia. Computers in the Schools, 33(1), 24-37.

Muthusamy, P., \& Farashaiyan, A. (2016). Situational variations in request and apology realization strategies among international postgraduate students at Malaysian universities. English Language Teaching, 9(3), 181. https://doi.org/10.5539/elt.v9n3p181

Mutiaraningrum, I. (2020). EFL teachers' beliefs and practices about digital learning of 
English. 5(2), 304-321.

Mutiaraningrum, I., \& Nugroho, A. (2020). Social construction of knowledge in synchronous text-based discussion during English language learning. Journal on English as a Foreign Language, 10(2), 315-336. https://doi.org/10.23971/jefl.v10i2.1934

Nartiningrum, N. (n.d.). Online learning amidst global pandemic: EFL students' challenges, suggestions, and needed materials. 4(2), 115-140.

Nugroho, A. (2019). Request realizations of Indonesian ESP lecturers. A Journal of Culture English Language Teaching Literature \& Linguistics, 6(1), 1. https://doi.org/10.22219/celticumm.vol6.no1.1-13

Nugroho, A. (2020). English material needs of accounting students: An English for specific purposes approach. 4778, 1-15. https://doi.org/10.24256/ideas.v8i1.1239

Nugroho, A., \& Atmojo, A. E. P. (2020). Digital learning of English beyond classroom: EFL learners' perception and teaching activities. JEELS (Journal of English Education and Linguistics Studies), 7(2), 219-243.

Nugroho, A., \& Rahmawati, A. (2020). "Let's write a caption!”: Utilizing Instagram to enhance ESP students' writing skills. JURNAL BASIS, 7(1), 1-12.

Nugroho, A., \& Rekha, A. (2020). Speech acts of requests: A case of Indonesian EFL learners. Journal of English Language Teaching and Linguistics, 5(1), 1-16.

Nugroho, A., Zamzami, M. R. A., \& Ukhrowiyah, N. F. (2020). Language input, learning environment, and motivation of a successful EFL learner. Journal on English as a Foreign Language, 10(1), 46-69. https://doi.org/10.23971/jefl.v10i1.1511

O'Flaherty, J., \& Phillips, C. (2015). The use of flipped classrooms in higher education: A scoping review. The Internet and Higher Education, 25, 85-95.

Phakiti, A. (2015). Experimental research methods in language learning. Bloomsbury Publishing.

Singay. (2020). Flipped learning in English as a second language classroom: Bhutanese students' perceptions and attitudes of flipped learning approach in learning grammar. Indonesian Journal of Applied Linguistics, 9(3), 666-674. https://doi.org/10.17509/ijal.v9i3.23217

Singay, S. (n.d.). Flipped learning in the English as a second language classroom: Bhutanese students' perceptions and attitudes of flipped learning approach in learning grammar. Indonesian Journal of Applied Linguistics, 9(3), 666-674.

Taguchi, N. (2006). Analysis of appropriateness in a speech act of request in L2 English. Pragmatics, 16(4), 513-533.

Wafa'A, H., \& Altakhaineh, A. R. M. (2019). The effect of flipped classroom instruction on developing Emirati EFL learners' pragmatic competence. International Journal of Learning, Teaching and Educational Research, 18(10), 89-111.

Webb, M., \& Doman, E. (2020). Impacts of flipped classrooms on learner attitudes towards technology-enhanced language learning. Computer Assisted Language Learning, 33(3), 240-274. https://doi.org/10.1080/09588221.2018.1557692

Yazdanfar, S., \& Bonyadi, A. (2016). Request strategies in everyday interactions of Persian and English speakers. SAGE Open, 6(4). https://doi.org/10.1177/2158244016679473

Zainuddin, Z., \& Perera, C. J. (2019). Exploring students' competence, autonomy and relatedness in the flipped classroom pedagogical model. Journal of Further and Higher Education, 43(1), 115-126. https://doi.org/10.1080/0309877X.2017.1356916 